\title{
TREATMENT ALTERNATIVES FOR MICROPOLLUTANT REMOVAL IN WASTEWATER
}

\author{
${ }^{1}$ Bilgehan NAS, ${ }^{2}$ Taylan DOLU, ${ }^{3}$ Havva ATEŞ, ${ }^{4}$ M.Emin ARGUN, ${ }^{5}$ Esra YEL \\ 1,23,4,5Selcuk University, Engineering Faculty, Department of Environmental Engineering, Konya, TURKEY \\ 1bnas@selcuk.edu.tr, 2taylandolu@selcuk.edu.tr, ${ }^{3 h}$ avvaates@selcuk.edu.tr, ${ }^{4}$ argun@selcuk.edu.tr, \\ 5etarlan@selcuk.edu.tr
}

(Geliş/Received: 10.11.2016; Kabul/Accepted in Revised Form: 16.02.2017)

\begin{abstract}
Present of micropollutants in aquatic environments has become an alarming environmental problem for both living creatures and environment. Micropollutants, also called as emerging contaminants arise from natural substances and increasing variety of anthropogenic events. Micropollutants consist of pharmaceuticals, personal care products, steroid hormones, industrial chemicals, pesticides, polyaromatic hydrocarbons and other recently seen compounds. These emerging contaminants are commonly found in very low concentration in different water bodies ranging from a few $\mathrm{ng} / \mathrm{l}$ to several $\mu \mathrm{g} / \mathrm{l}$.

Many existing Wastewater Treatment Plants (WWTPs) in all over the world are not especially designed for removing micropollutants. Low concentration and diversity of micropollutants complicate the dedection and analysis procedures during the treatment processes. Furthermore, entering micropollutants to the WWTPs continuously and stable structure of many micropollutants make difficult to eliminate these emerging compounds sufficiently. Therefore, many micropollutants of unknown concentration pass to aquatic environment from WWTPs. The occurence of micropollutants with a significant levels in aquatic environments disrupt the aquatic ecosystems with a number of adverse effects including short-term and long-term toxicity such as endocrine disrupting effects. Besides the known negative effects of micropollutants there are great number of micropollutants whose effects on living organisms are still unknown. As a result, removing these compounds is of a great importance both to protect environmental ecosystem and human health. Considering that the conventional methods are insufficient for removing the micropollutants other alternative treatment methods including coagulation-flocculation, activated carbon adsorption (powdered activated carbon and granular activated carbon), advanced oxidation processes (AOPs), membrane processes and membrane bioreactor can be applied for better removal.

In this study, alternative treatments methods and removal efficiencies of each treatment methods on different micropollutants were investigated and all alternative treatment methods were compared between each other in terms of micropollutant removal rates.
\end{abstract}

Key Words: Micropollutants, Removal efficiency, Wastewater, Wastewater treatment plants.

\section{Atık Sularda Mikrokirletici Giderimi İçin Alternatif Arıtımlar}

ÖZ: Mikro kirleticilerin sucul ortamlarda bulunması hem canlılar hem de çevre için endişe verici bir çevre sorunu haline gelmiştir. Hızla ortaya çıkan/gelişen kirleticiler olarak da adlandırılan mikro kirleticiler doğal maddelerden ve giderek artan çeşitli antropojenik olaylardan meydana gelmektedir. Mikrokirleticiler farmasötikler, kişisel bakım ürünleri, steroid hormonlar, endüstriyel kimyasallar, pestisitler, poliaromatik hidrokarbonlar ve son zamanlarda görülen diğer bileşiklerden oluşmaktadır. $\mathrm{Bu}$ kirleticiler farklı su kaynaklarında genellikle birkaç ng /L ile $\mu \mathrm{g} / \mathrm{L}$ arasında değişen çok düşük 
konsantrasyonlarda bulunmaktadır. Dünyadaki mevcut birçok Atıksu Arıtma Tesisi (AAT) özellikle mikro kirleticileri gidermek için tasarlanmamıştır. Mikro kirleticilerin düşük konsantrasyonda bulunmaları ve çok çeşitli olmaları arıtma prosesleri boyunca belirleme ve analiz prosedürlerini zorlaştırmaktadır. Ayrıca, mikro kirleticilerin AAT’lerine sürekli olarak gelmeleri ve birçok mikro kirleticinin kararlı yapıya sahip olması bu kirleticilerin yeteri kadar giderilmesini zorlaştırmaktadır. Bu sebeple, mikro kirleticilerin birçoğu bilinmeyen konsantrasyonları ile beraber AAT'lerinden sucul çevrelere geçmektedir. Sucul ortamlarda ciddi seviyelerde mikro kirletici oluşumları kısa vadeli ve uzun vadeli toksisiteyi de içeren endokrin bozucu etkiler gibi bir dizi olumsuz etkiler ile beraber sucul ekosistemleri bozmaktadır. Olumsuz etkileri bilinen mikro kirleticilerin yanı sıra canlı organizmalar üzerindeki etkileri hala bilinmeyen çok sayıda mikro kirletici de vardır. Sonuç olarak bu kirleticilerin giderimi, hem çevresel ekosistemlerin hem de insan sağlı̆̆ının korunması için büyük bir önem taşımaktadır. Mikro kirleticilerin gideriminde klasik yöntemlerin yetersiz olduğu göz önünde bulundurulursa daha iyi giderim verimleri için koagülasyon - flokülasyon, aktif karbon adsorpsiyonu (toz aktif karbon ve granül aktif karbon), ileri oksidasyon prosesleri (İOP), membran prosesleri ve membran biyoreaktörü içeren diğer alternatif arıtma yöntemleri uygulanabilir.

$\mathrm{Bu}$ çalışmada; alternatif arıtma yöntemleri ve her bir arıtma yönteminin farklı mikro kirleticiler üzerindeki giderim verimleri araştırılarak, bütün alternatif arıtım yöntemleri mikro kirletici giderim verimleri bakımından birbirleri ile kıyaslanmıştır.

Anahtar Kelimeler: Atık su, Atıksu arıtma tesisleri, Giderim verimi, Mikro kirleticiler

\section{INTRODUCTION}

Especially in recent years found in various water bodies in different places, micropollutants are contaminate of potential concern for both aquatic environment and human health. Continuously increasing concentration of these contaminants arise from natural substances and increasing variety of anthropogenic events. Also called as emerging compounds, micropollutants include pharmaceuticals, personal care products, steroid hormones, industrial chemicals, pesticides and polyaromatic hydrocarbons. Toxic properties and effects on living organisms of most micropollutants are still unknown. Therefore, removal of these contaminants become more of an issue.

Many existing Wastewater Treatment Plants (WWTPs) in all over the world are not especially designed for removing micropollutants. Micropollutants may enter the receiving water bodies without the complete removal because of their different physical properties and stable structures. In addition to this, monitoring of micropollutants in different treatment units present in WWTPs and taking the necessary precautions for their removal in WWTPs are insufficient. (Bolong et al., 2009). As a consequence, present in water bodies, these emerging compounds pose risk especially drinking water industries and natural life. Micropollutants are associated with adverse events such as endocrine disrupting effects, short term and long term toxicities for different species and acquiring antibiotic resistance of microorganisms (Fent et al., 2006; Pruden et al., 2006).

There are very few discharge standards and discharge regulations present for micropollutants at the present time. Only some countries have made regulations for a small number of micropollutants. Arrangements made by the countries mostly about surfactants, industrial chemicals and pesticides. However, pharmaceuticals, personal care products and steroid hormones are not in the list. Toxicological effects of microorganisms and responses of species to micropollutants should be investigated in advanced level in order to set the right limits for varied types of micropollutant groups. Furthermore, in addition to singular effects of micropollutants scientists should carry out an experiment to gain insight about synergistic effects of micropollutants. 


\section{TREATMENT ALTERNATIVES FOR MICROPOLLUTANT REMOVAL}

There is no specific treatment for complete removal of all micropollutant groups because of distinctive properties of them. Also, treatment processes can not eliminate both bulk substances and micropollutants together with a very high removal efficiencies. Treatment options used for micropollutants are coagulation-flocculation, activated carbon adsorption (PAC and GAC), ozonation and advanced oxidation processes (AOPs), membrane processes and membrane bioreactor (MBR).

\section{Coagulation-flocculation}

Coagulation-flocculation process generally used to remove colloids and some of the dissolved particulate matter. Table -1 shows the removal efficiencies of some most studied micropollutants treated by coagulation-flocculation process.

Table 1. Removals of some micropollutants during coagulation-flocculation process (Suárez et al., 2009)

\begin{tabular}{|cccc|}
\hline Coagulant & Dosage and pH & Compounds & Removal efficiency (\%) \\
\hline $\mathrm{FeCl}_{3} / \mathrm{Al}_{2}\left(\mathrm{SO}_{4}\right)_{3}$ & $25,50 \mathrm{ppm}$ and 7 & Ibuprofen & $12.0 \pm 4.8$ \\
$\mathrm{FeCl}_{3} / \mathrm{Al}_{2}\left(\mathrm{SO}_{4}\right)_{3}$ & $25,50 \mathrm{ppm}$ and 7 & Diclofenac & $21.6 \pm 19.4$ \\
$\mathrm{FeCl}_{3} / \mathrm{Al}_{2}\left(\mathrm{SO}_{4}\right)_{3}$ & $25,50 \mathrm{ppm}$ and 7 & Naproxen & $31.8 \pm 10.2$ \\
$\mathrm{FeCl}_{3} / \mathrm{Al}_{2}\left(\mathrm{SO}_{4}\right)_{3}$ & $25,50 \mathrm{ppm}$ and 7 & Carbamazepine & $6.3 \pm 15.9$ \\
$\mathrm{FeCl}_{3} / \mathrm{Al}_{2}\left(\mathrm{SO}_{4}\right)_{3}$ & $25,50 \mathrm{ppm}$ and 7 & Sulfamethoxazole & $6.0 \pm 9.5$ \\
$\mathrm{FeCl}_{3} / \mathrm{Al}_{2}\left(\mathrm{SO}_{4}\right)_{3}$ & $25,50 \mathrm{ppm}$ and 7 & Tonalide & $83.4 \pm 14.3$ \\
$\mathrm{FeCl}_{3} / \mathrm{Al}_{2}\left(\mathrm{SO}_{4}\right)_{3}$ & $25,50 \mathrm{ppm}$ and 7 & Galaxolide & $79.2 \pm 9.9$ \\
\hline
\end{tabular}

In general, coagulation-flocculation processes are ineffective for eliminating the most of micropollutants. Matamoros and Salvadó (2013) evaluated the removal efficiencies of micropollutants in a coagulation/flocculation-lamellar clarifier. Maximum removal efficiency was found \% 50. (Suárez et al., 2009) treated hospital wastewater by coagulation-flocculation and reported significant reduction (about $\%$ 80) of musks such as galaxolide and tonalide. Other removal efficiencies are $46 \%, 42 \%, 23 \%$ respectively for diclofenac, naproxen and ibuprofen. Another study done by Asakura and Matsuto (2009) revealed that treating landfill leachate by coagulation and sedimentation was not able to remove bisphenol A but removal efficiencies of DEHP (70 \%) and nonylphenol (90\%) were evaulated as pretty good.

Considering all of these, coagulation-flocculation processes provide a low removal efficiencies for most of micropollutants except for some musks and pharmaceuticals such as diclofenac and nonylphenol. This treatment technique also gives poor results for pesticides. Furthermore, neither coagulant dose nor operation temperature influence the pesticides removal efficiencies substantially (Thuy et al., 2008). Composition of wastewater treated by coagulation-flocculation processes influence the removal rates of micropollutants negatively or positively. For instance, wastewater having a high content of fat improve the removal efficiencies of hydrophobic compounds (Suárez et al., 2009). Besides, dissolved humic acid could increase the removal rates of pharmaceutical compounds such as diclofenac, ibuprofen and bezafibrate (Vieno et al., 2006). Conversely, present of dissolved organic matter in wastewater may inhibit the removal of micropollutants (Choi et al., 2008). Apart from all these, mixing conditions, $\mathrm{pH}$, alkalinity and temperature also influence the performance of coagulation-flocculation (Alexander et al., 2012).

\section{Activated carbon adsorption}

Active carbon adsorption is generally used for taste and odor control especially in drinking water. Active carbon adsorption give better removal results in secondary effluent treatment. Compared with coagulation-flocculation process, this technique is more effective method for removing micropollutants 
(Choi et al., 2008). Both powdered activated carbon (PAC) and granular activated carbon (GAC) have been commonly used in adsorption applications. In these processes, removal efficiencies may vary based on properties of both used adsorbate and adsorbent (Kovalova et al., 2013).

\section{Powdered activated carbon (PAC)}

Powdered activated carbon (PAC) is considered as an effective adsorbent for treating resistant and non-biodegradable organic compounds. Advantages of using PAC is that continuously provide fresh carbon and can be used in certain circumstances when the concentration's of contaminants rise in water bodies (Snyder et al., 2007). Study done by Kovalova et al. (2013), PAC treatment was used to evaluate removal efficiencies of micropollutants in MBR treated hospital wastewater. In this study retention time was chosen as 2 days and PAC dosages were also selected as 8,23 and $43 \mathrm{mg} / \mathrm{L}$. According to the results PAC reactor reached substantial removal efficiencies especially for pharmaceuticals, metabolites and industrial chemicals. The elimination rate of total load was found around $86 \%$. Hernández-Leal et al. (2011) conducted batch tests and determined high removal rates (>94\%) for personal care products, bisphenol A and nonylphenol.

PAC reactors used for removing the micropollutants depends on many factors like PAC dosage, contact time, physical properties of targeted compounds and composition of wastewater (Boehler et al., 2012; Snyder et al., 2007). Westerhoff et al. (2005) found in their study that higher PAC dosages (20 $\mathrm{mg} / \mathrm{L}$ ) improve the removal efficiencies of micropollutants regardless of micropollutant's initial concentaration. Addition of PAC in WWTPs seems an effective method for enhancing the removal rates of micropollutants (Bolong et al., 2009).

\section{Granular activated carbon (GAC)}

Rossner et al. (2009) asserted that granul active carbon (GAC) dose ( $<10 \mathrm{mg} / \mathrm{L})$ used for controlling the odor and taste in drinking water is sufficient for treatment of various compound up to efficient removal rates of $99 \%$ in lake water. Removal efficiencies of steroidal estrogens and pharmaceuticals were determined in a full-scale granular activated carbon plant treating WWTP's effluent. Higher elimination rates achieved for steroidal estrogens but elimination rates for pharmaceuticals were evaluated in low levels. Removal efficiencies of mebeverine, indomethacine, and diclofenac ranged in 84 $-99 \%$. Hovewer, removal efficiencies of carbamazepine and propranolol ranged only $17-23 \%$ (Grover et al., 2011).

Similar to PAC, contact time of process influence the efficacy of GAC. Low contact time reduce the adsorption performance of GAC reactor significantly. In general, removal of compounds depens upon interactions between particle and contaminant and pore blocking (Bolong et al., 2009). Therefore, treating highly contaminated wastewater by GAC gives poor results.

As a whole, such studies show that GAC and PAC processes can be considered as effective methods in the matter of removing micropollutants. In general, higher elimination rates of micropollutants can be provided by non-polar characteristics of targeted compounds and high compliance of pore size with shape of contaminants (Rossner et al., 2009; Verlicchi et al., 2010). Nevertheless, blocking of pores due to existing natural organic matter (NOM) reduces the active carbon efficiency. 
Table 2. Removals of some micropollutants during adsorption process (Kovalova et al., 2013; Grover et al., 2011)

\begin{tabular}{|cccc|}
\hline Adsorbent & Dosage & Compounds & Removal efficiency (\%) \\
\hline PAC & $8,23,43 \mathrm{mg} / \mathrm{L}$ & Diclofenac & $96,98,99$ \\
PAC & $8,23,43 \mathrm{mg} / \mathrm{L}$ & Carbamazepine & $98,99,100$ \\
PAC & $8,23,43 \mathrm{mg} / \mathrm{L}$ & Propranolol & $>91,>94,>94$ \\
PAC & $8,23,43 \mathrm{mg} / \mathrm{L}$ & Sulfamethoxazole & $2,33,62$ \\
GAC & Full scale & Diclofenac & $>98$ \\
GAC & Full scale & Carbamazepine & 23 \\
GAC & Full scale & Propranolol & 17 \\
GAC & Full scale & Estrone & 64 \\
GAC & Full scale & 17 $\beta$-Estradiol & $>43$ \\
GAC & Full scale & $17 \alpha$-Ethinylestradiol & $>43$ \\
\hline
\end{tabular}

\section{Ozonation and advanced oxidation processes (AOPs)}

Conventional physicochemical and biological treatments are not efficient for removing most varied micropollutants because of persistent structure of micropollutants. In such circumstances, ozonation and advanced oxidation processes (AOPs) can be considered as a solution. Having a high degradation rates, this technology is not selective for contaminants to remove them. Besides, these processes have a disinfecting effect for reuse of water (Hernández-Leal et al., 2011). Ozone degrades the contaminants directly or indirectly but mainly by the production of hydroxyl radicals $(\bullet \mathrm{OH})$ which are stronger and less selective for emerging compounds. Some of the micropollutants are sensitive to both ozone and AOPs such as naproxen but some of them are only sensitive to hydroxyl radicals like atrazine. Nonetheless, some of them like TCEP and TCPP are resistant to both ozonation and forms of oxidation (Gerrity et al., 2011). Present of $\mathrm{H}_{2} \mathrm{O}_{2}$, fenton reagent and ultraviolet may promote the production of hydroxyl radicals.

Ozonation is a promising method for removing micropollutants in a full scale WWTPs (Hollender et al., 2009). Hernández-Leal et al. (2011) investigated the elimination rates of micropollutants in biologically treated grey water by ozonation with a ozone dose of $5 \mathrm{mg} / \mathrm{L}$. In general, all micropollutants selected treated substantial levels. Under the same conditions with the only difference ozone dose of 5 $\mathrm{mg} / \mathrm{L}$ showed higher removal efficiencies for most of micropollutants (Sui et al., 2010). Especially removal rates of carbamazepine, diclofenac, indomethacin, sulpiride and trimethoprim exceeded $95 \%$. However, removal rate of bezafibrate was evaluated only $14 \%$ because of bezafibrate's stable molecular structure. (Kim et al., 2009) compared the removal efficiencies of pharmaceutical compounds using UV process alone and using both $\mathrm{UV}$ and $\mathrm{H}_{2} \mathrm{O}_{2}$ together. The results show that $\mathrm{UV}$ process alone only achieved high removal rates ( $>90 \%$ ) for ketoprofen, diclofenac and antipyrine but elimination rates for macrolides ranged between $24-34 \%$. Other study demonstrated that $\mathrm{UV}$ and $\mathrm{H}_{2} \mathrm{O}_{2}$ together achieved much higher efficiencies for most of micropollutants. Besides, it is found that under the same conditions when UV applied to fenton process total removal rates increased. In addition to this, present of dissolved organic matter in wastewater promotes the elimination rates of micropollutants.

Oxidation processes can not provide a complete mineralization of these emerging compound so byproducts and metabolites arised from these reactions (Hollender et al., 2009; Reungoat et al., 2011). Activated carbon filtration or sand filtration may be applied to reduce these undesirable compounds. 
Table 3. Removals of some micropollutants during ozonation and AOPs (Luo et al., 2014)

\begin{tabular}{|ccc|}
\hline Treatment (Dose) & Compounds & Removal efficiency (\%) \\
\hline $\mathrm{O}_{3}(5 \mathrm{mg} / \mathrm{L})$ & Carbamazepine & $>90$ \\
$\mathrm{O}_{3}(5 \mathrm{mg} / \mathrm{L})$ & Diclofenac & $>90$ \\
$\mathrm{O}_{3}(5 \mathrm{mg} / \mathrm{L})$ & Metoprolol & $80-90$ \\
$\mathrm{O}_{3}(5 \mathrm{mg} / \mathrm{L})$ & Bezafibrate & $0-50$ \\
$\mathrm{O}_{3}(5 \mathrm{mg} / \mathrm{L})$ & Trimethoprim & $>90$ \\
$\mathrm{O}_{3}(5 \mathrm{mg} / \mathrm{L})$ & DEET & $50-80$ \\
$\mathrm{O}_{3}(5 \mathrm{mg} / \mathrm{L})+\mathrm{H}_{2} \mathrm{O}_{2}(3.5 \mathrm{mg} / \mathrm{L})$ & Ibuprofen & 83 \\
$\mathrm{O}_{3}(5 \mathrm{mg} / \mathrm{L})+\mathrm{H}_{2} \mathrm{O}_{2}(3.5 \mathrm{mg} / \mathrm{L})$ & Diclofenac & $>99$ \\
$\mathrm{O}_{3}(5 \mathrm{mg} / \mathrm{L})+\mathrm{H}_{2} \mathrm{O}_{2}(3.5 \mathrm{mg} / \mathrm{L})$ & Carbamazepine & $>99$ \\
$\mathrm{O}_{3}(5 \mathrm{mg} / \mathrm{L})+\mathrm{H}_{2} \mathrm{O}_{2}(3.5 \mathrm{mg} / \mathrm{L})$ & Sulfamethoxazole & 98 \\
$\mathrm{O}_{3}(5 \mathrm{mg} / \mathrm{L})+\mathrm{H}_{2} \mathrm{O}_{2}(3.5 \mathrm{mg} / \mathrm{L})$ & Triclosan & $>99$ \\
$\mathrm{O}_{3}(5 \mathrm{mg} / \mathrm{L})+\mathrm{H}_{2} \mathrm{O}_{2}(3.5 \mathrm{mg} / \mathrm{L})$ & Bisphenol A & $>78$ \\
$\mathrm{O}_{3}(5 \mathrm{mg} / \mathrm{L})+\mathrm{H}_{2} \mathrm{O}_{2}(3.5 \mathrm{mg} / \mathrm{L})$ & Estradiol & $>83$ \\
$\mathrm{O}_{3}(5 \mathrm{mg} / \mathrm{L})+\mathrm{H}_{2} \mathrm{O}_{2}(3.5 \mathrm{mg} / \mathrm{L})$ & Estrone & $>98$ \\
$\mathrm{O}_{3}(5 \mathrm{mg} / \mathrm{L})+\mathrm{H}_{2} \mathrm{O}_{2}(3.5 \mathrm{mg} / \mathrm{L})$ & Atrazine & 69 \\
\hline
\end{tabular}

\section{Membrane processes}

Generally, elimination of micropollutants by membrane processes achieved by adsorption onto membrane, size of pores and charge repulsion. Removal efficiencies of membrane processes largely depends on type of membrane process, characteristics of membrane, blocking of membrane pores, operating conditions and properties of selected micropollutants (Schäfer vd., 2011).

Although microfiltration (MF) and ultrafiltration (UF) are highly efective processes for eliminating the turbidity, they are insufficient in removing micropollutants because of micropollutant's molecular sizes. However, micropollutants can be removed via interaction with natural organic matter (NOM) or adsorption onto membrane polymers. Jermann et al. (2009) investigated the removal efficiencies of ibuprofen and estradiol by UF without existing the NOM. In hydrophilic UF membrane, elimination rate of ibuprofen and estradiol were found negligible and $8 \%$ respectively. However in hydrophobic membrane, removal efficiencies of ibuprofen and estradiol increased up to around $25 \%$ and $80 \%$ respectively. Generally, MF and UF processes are not used alone in elimination of micropollutants because of their poor performance. Therefore, these processes should be combined with other treatment methods such as nanofiltration (NF) or reverse osmosis (RO). Garcia et al. (2013) combined the MF and RO processes in order to remove micropollutants for reuse of domestic wastewater. For example, DEHP was removed up to $50 \%$ with only microfiltration treatment. However, combined system of MF and RO improved the elimination rates of micropollutants. Removal efficiencies of micropollutants ranged between $65 \%$ and $90 \%$ except ibuprofen and nonylphenol. In other study, combined system of MF and $\mathrm{RO}$ also showed a significant removal efficiencies ( $>95 \%)$ for most micropollutants except mefenamic acid and caffeine (Sui et al., 2010).

Reverse osmosis has a great potential for almost complete removal of micropollutants. YangaliQuintanilla et al. (2011) compared the treatment performance of nanofiltratin and reverse osmosis for pharmaceuticals, pesticides, endocrine disruptors. Elimination rates of micropollutants achieved by NF was similar to RO's results. Removal efficiencies for neutral contaminants and ionic contaminants treated by NF were evaluated as $82 \%$ and $97 \%$ respectively. The removal efficiencies of the same contaminants treated by $\mathrm{RO}$ were found as $85 \%$ and $99 \%$ recpectively. 
Table 4. Removals of some micropollutants during membrane processes (Jermann et al., 2009; Yangali-Quintanilla et al., 2011)

\begin{tabular}{|ccccc|}
\hline Membrane & Water type & Membrane type & Compounds & Removal efficiency (\%) \\
\hline UF & Synthetic water & PES flat-sheet & Ibuprofen & 7 \\
UF & Synthetic water & RC4 flat-sheet & Ibuprofen & Negligible \\
UF & Synthetic water & PES flat-sheet & Estradiol & Up to 80 \\
UF & Synthetic water & RC4 flat-sheet & Estradiol & Up to 25 \\
RO & Secondary effluent & Filmtec TW30 & Ibuprofen & $>99$ \\
RO & Secondary effluent & Filmtec TW30 & Sulfonamides & $>93$ \\
RO & Secondary effluent & Filmtec TW30 & Diclofenac & 95 \\
RO & Secondary effluent & Filmtec TW30 & Macrolides & $>99$ \\
RO & Secondary effluent & Filmtec TW30 & Bisphenol A & $>99$ \\
\hline
\end{tabular}

\section{Membrane bioreactor (MBR)}

Membrane bioreactor (MBR) processes combine the activated sludge biological treatment and membrane filtration (MF or NF). There are many advantages of using this technology compared with conventional WWTPs. These advantages includes higher effluent quality, higher biomass concentration, accurate control of SRTs, less space requirement, minimum rising sludge problem and transforming flexibility of present WWTPs to MBR systems (Ngo et al., 2012). MBR technique has a great potential to remove a wide variety of micropollutants including emerging compounds resistant to activated sludge processes (Radjenovic et al., 2009). Elimination of micropollutants by MBR treatment mainly depens on SRT, concentration, contents of wastewater, $\mathrm{pH}$, conductivity and operating temperature (Kovalova et al., 2012).

(Trinh et al., 2012) investigated the removal efficiencies of micropollutants in a full scale MBR process. Higher elimination rates ( $>90 \%)$ were found most of the micropollutants. Hovewer, removal efficiencies of amitriptyline, carbamazepine, diazepam, diclofenac, fluoxetine, gemfibrozil, omeprazole, sulfamethoxazole and trimethoprim ranged between $24-68 \%$. These compounds can be considered as indicator becalse of their low removal rates in MBR treatment. Main source of pharmaceuticals is waste/wastewater arised from hospitals (Verlicchi et al., 2010). (Kovalova et al., 2012) investigated the fate of micropollutants in MBR process treating hospital effluent. Hence, composition of wastewater mainly comprising of iodinated contrast media total removal rates of pharmaceuticals and metabolites were evaluated as only $22 \%$. But, the total reduction would be up to $90 \%$ if these content were neglected. (Beier et al., 2011) suggested that hospital effluents could be treated efficiently in a case of maintaining a very high sludge age (>100 days) in MBR systems especially designed for treating hospital effluent.

Conventional activated sludge processes and MBR technology usually compared with each other in terms of eliminating micropollutants. (Radjenovic et al., 2007) compared the treatment performance of laboratory scale MBR process and conventional activated sludge in terms of eliminating pharmaceuticals. Both two system treated naproxen, ibuprofen, acetaminophen, hydrochlorothiazide, and paroxetine in high levels. Nevertheless, the result showed that MBR system were relatively stable for eliminating various micropollutants and treated most micropollutants slightly higher than conventional activated sludge process.

Like other treatment technologies, MBR processes also influenced by a number of factors such as SRT, HRT and operating temperature. In general, MBR systems operated at high sludge age provide higher removal efficiency for micropollutants due to present of diverse microorganisms in wastewater (Roh et al., 2009). 
Table 5. Removals of some micropollutants during MBR processes (Trinh et al., 2012; Beier et al., 2011)

\begin{tabular}{|cccc|}
\hline Water type & Membrane type & Compounds & $\begin{array}{c}\text { Removal } \\
\text { efficiency (\%) }\end{array}$ \\
\hline Raw wastewater & Full-scale hollow fiber & Ibuprofen & $\sim 100$ \\
Raw wastewater & Full-scale hollow fiber & Diclofenac & 43 \\
Raw wastewater & Full-scale hollow fiber & Carbamazepine & 24 \\
Raw wastewater & Full-scale hollow fiber & Sulfamethoxazole & 60 \\
Raw wastewater & Full-scale hollow fiber & Trimethoprim & 30 \\
Raw wastewater & Full-scale hollow fiber & Estrone & $\sim 100$ \\
Raw wastewater & Full-scale hollow fiber & Estriol & $\sim 100$ \\
Raw wastewater & Full-scale hollow fiber & BisphenolA & $\sim 100$ \\
Hospital effluent & Full-scale flat sheet & Ibuprofen & $>80$ \\
Hospital effluent & Full-scale flat sheet & Carbamazepine & $<20$ \\
Hospital effluent & Full-scale flat sheet & Diclofenac & $<20$ \\
\hline
\end{tabular}

\section{RESULT AND DISCUSSION}

Nowadays, micropollutants are often dedected in important drinking water sources, lakes, rivers, groundwaters and wastewaters. Existing of micropollutants in higher concentration in various water bodies in different parts of world threatens both human health and aquatic ecosystem seriously.

Hence WWTPs are not able to provide a complete elimination for micropollutants it is necessary to use the appropriate treatment processes to reduce the ecotoxicological effects of micropollutants on living organisms. Most of existing conventional WWTP's removal performance of micropollutants are ineffective because of being in a low concentration of micropollutants in wastewater and diverse physicochemical properties of micropollutants. Especially, micropollutants having polar molecular structure and which are nonbiodegradable generally pass from WWTPs to receiving water body without sufficient treatment rates. Therefore, optimization and upgrading of current treatment processes in WWTPs is crucial to reduce loading rates of micropollutants.

Besides the conventional treatment processes coagulation-flocculation, activated carbon adsorption (powdered activated carbon and granular activated carbon), advanced oxidation processes (AOPs), membrane processes and membrane bioreactor also used for elimination of micropollutants. Among these treatment techniques, advanced oxidation processes and membrane systems come to the forefront. Although these treatment processes are very efficient in removing micropollutants they have also disadvantages such as causing production of new by-products and metabolites and higher operating costs. Both providing complete elimination of micropollutants and preventing the occurrence of byproducts and other contaminants, combined treatments should be preferred.

\section{ACKNOWLEDGMENT}

This study was supported by TÜBİTAK project (115Y167).

\section{REFERENCES}

Alexander, J.T., Hai, F.I., Al-aboud, T.M.., 2012, “Chemical Coagulation-Based Processes for Trace Organic Contaminant Removal: Current State And Future Potential" Journal of Environmental Management, Vol. 111, pp. 195-207.

Asakura, H., Matsuto T., 2009, " Experimental Study of Behavior of Endocrine-Disrupting Chemicals in Leachate Treatment Process and Evaluation of Removal Efficiency", Waste Management, Vol. 29, pp.1852-1859. 
Beier, S., Cramer, C., Koster, S., Mauer, C., Palmowski, L., Schroder, H., et al., 2011, "Full Scale Membrane Bioreactor Treatment of Hospital Wastewater as Forerunner for Hot-spot Wastewater Treatment Solutions in High Density Urban Areas", Water Science and Technology, Vol. 63 (1), pp. 66-71.

Boehler, M., Zwickenpflug, B., Hollender, J., Ternes, T., Joss, A., Siegrist, H., 2012, "Removal of Micropollutants in Municipal Wastewater Treatment Plants by Powder-Activated Carbon", Water Science and Technology Vol., 66, pp. 2115-2121.

Bolong, N., Ismail, A.F., Salim, M.R., Matsuura, T., 2009, “ A Review of The Effects of Emerging Contaminants in Wastewater and Options for Their Removal", Desalination, Vol. 239, pp. 22946.

Choi, K.J., Kim S.G., Kim S.H., 2008, "Removal of Antibiotics by Coagulation and Granular Activated Carbon Filtration", Journal of Hazardous Materials, Vol. 151, pp. 38-43.

Fent, K., Weston, A.A, Carminada, D., 2006, "Ecotoxicology of Human Pharmaceuticals", Aquatic Toxicology , Vol. 76 (2), pp. 122-159.

Garcia, N., Moreno, J., Cartmell, E., Rodriguez-Roda, I., Judd, S., 2013, “The Application of Microfiltration-Reverse Osmosis/Nanofiltration to Trace Organics Removal for Municipal Wastewater Reuse" Environmental Technology, Vol. 34 (24), pp. 3183-3189.

Gerrity, D., Gamage, S., Holady, J.C., Mawhinney, D.B., Quinones, O., Trenholm, R.A., et al., 2011, "Pilot-scale Evaluation of Ozone and Biological Activated Carbon for Trace Organic Contaminant Mitigation and Disinfection", Water Research, Vol. 45 (5), pp. 2155-2165.

Grover, D.P., Zhou, J.L., Frickers, P.E., Readman, J.W., 2011, “Improved Removal of Estrogenic and Pharmaceutical Compounds in Sewage Effluent by Full Scale Granular Activated Carbon: Iimpact on Receiving River Water", Journal of Hazardous Materials, Vol. 185 (2), pp. 10051011.

Hernández-Leal, L., Temmink, H., Zeeman, G., Buisman, C.J.N., 2011, “Removal of Micropollutants from Aerobically Treated Grey Water via Ozone and Activated Carbon", Water Research, Vol. 45 (9), pp. 2887-2896.

Hollender, J., Zimmermann, S.G., Koepke, S., Krauss, M., McArdell, C.S., Ort, C., et al., 2009, "Elimination of Organic Micropollutants in a Municipal Wastewater Treatment Plant Upgraded with a Full-scale Post-ozonation Followed by Sand Filtration", Environmental Science \& Technology, Vol. 43 (20), pp. 7862-7869.

Jermann, D., Pronk, W., Boller, M., Schäfer, A.I., 2009, “The Role of NOM Fouling for The Retention of Estradiol and Ibuprofen During Ultrafiltration", Journal of Membrane Science, Vol. 329, pp. 75-84.

Kim, I., Yamashita, N., Tanaka, H., 2009, " Performance of UV and UV/H2O2 Processes for The Removal of Pharmaceuticals Detected in Secondary Effluent of a Sewage Treatment Plant in Japan", Journal of Hazardous Materials, Vol. 166 (2), pp. 1134-1140.

Kovalova, L., Siegrist, H., Singer, H., Wittmer, A., McArdell, C.S., 2012, "Hospital Wastewater Treatment by Membrane Bioreactor: Performance and Efficiency for Organic Micropollutant Elimination", Environmental Science \& Technology, Vol. 46 (3), pp. 1536-1545.

Kovalova, L., Siegrist, H., von Gunten, U., Eugster, J., Hagenbuch, M., Wittmer, A., et al., 2013, "Elimination of Micropollutants During Post-Treatment of Hospital Wastewater with Powdered Activated Carbon, Ozone, and UV", Environmental Science \& Technology, Vol. 47 (149, pp. 7899-7908.

Luo, Y., Guo, W., Ngo, H.H., Nghiem, L.D., Hai, F.I., Zhang, J., Liang, S., Wang Xiaochang C., 2014, “A Review on The Occurrence of Micropollutants in The Aquatic Environment and Their Fate and Removal During Wastewater Treatment", Science of the Total Environment, Vol. 473-474, pp. 619-641.

Matamoros, V., Salvadó, V., 2013, “Evaluation of a Coagulation/flocculation-lamellar Clarifier and Filtration-UV-chlorination Reactor for Removing Emerging Contaminants at Full-scale 
Wastewater Treatment Plants in Spain", Journal of Environmental Management, Vol. 117, pp. 96-102.

Ngo, H., Guo,W., Vigneswaran, S., Chapter 8:Membrane Processes Forwater Reclamation and Reuse. In: Zhang, T.C., Surampalli, R.Y., Vigneswaran, S., Tyagi, R.D., Ong, S.L., Kao, C.M., editors. 2012, "Membrane Technology and Environmental Applications", USA: American Society of Civil Engineers (ASCE). pp. 239-75.

Pruden, A., Pei, R., Storteboom, H., Carlson, K.H., 2006, "Antibiotic Resistance Genes as Emerging Contaminants: Studies in Northern Colorado", Environmental Science \& Technology, Vol. 40 (23), pp. 7445-7450.

Radjenovic, J., Petrovic, M., Barceló, D., 2009, “Fate and Distribution of Pharmaceuticals in Waste-Water and Sewage Sludge of The Conventional Activated Sludge (CAS) and Advanced Membrane Bioreactor (MBR) Treatment", Water Research, Vol. 43 (3), pp. 831-841.

Radjenovic, J., Petrovic, M., Barceló, D., 2007, “Analysis of Pharmaceuticals in Wastewater and Removal Using a Membrane Bioreactor", Analytical and Bioanalytical Chemistry, Vol. 387 (4), pp. 1365-1377.

Reungoat, J., Escher, B.I., Macova, M., Keller, J., 2011, “Biofiltration of Wastewater Treatment Plant Effluent: Effective Removal of Pharmaceuticals and Personal Care Products and Reduction of Toxicity", Water Research, Vol. 45 (9), pp. 2751-2762.

Roh, H., Subramanya, N., Zhao, F., Yu, C.P, Sandt, J., Chu, K-H., 2009, "Biodegradation Potential of Wastewater Micropollutants by Ammonia-Oxidizing Bacteria", Chemosphere, Vol. 77 (8), pp. 1084-1089.

Rossner, A., Snyder, S.A., Knappe, D.R.U., 2009, “Removal of Emerging Contaminants of Concern by Alternative Adsorbents", Water Research, 43 (15), pp. 3787-3796.

Schäfer, A.I., Akanyeti, I., Semião, A.J.C., 2011, "Micropollutant Sorption to Membrane Polymers: a Review of Mechanisms for Estrogens", Advances in Colloid and Interface Science, Vol. 164, pp. 100-117.

Snyder, S.A., Adham, S., Redding, A.M., Cannon, F.S., DeCarolis, J., Oppenheimer, J., et al., 2007, “Role of Membranes and Activated Carbon in The Removal of Endocrine Disruptors and Pharmaceuticals", Desalination, Vol. 202, pp. 156-181.

Suárez, S., Lema, J.M., Omil, F., 2009, "Pre-treatment of Hospital Wastewater by CoagulationFlocculation and Flotation", Bioresource Technology, Vol. 100 (7), pp. 2138-2146.

Sui, Q., Huang, J., Deng, S., Yu, G., Fan, Q., 2010, “Occurrence and Removal of Pharmaceuticals, Caffeine and DEET in Wastewater Treatment Plants of Beijing, China", Water Research, Vol. 44 (2), pp. 417-426.

Thuy, P.T., Moons, K., Van Dijk, J.C., Viet Anh, N., Van der Bruggen, B., 2008, “To What Extent are Pesticides Removed from Surface Water During Coagulation-Flocculation", Water and Environment Journal, Vol. 22 (3), pp. 217-223.

Trinh, T., van den Akker, B., Stuetz, R.M., Coleman, H.M., Le-Clech, P., Khan, S.J., 2012,."Removal of trace organic chemical contaminants by a membrane bioreactor", Water Science and Technology, Vol. 66 (9), pp. 1856-1863.

Verlicchi, P., Galletti, A., Petrovic, M., Barceló, D., 2010, “Hospital Effluents as a Source of Emerging Pollutants: an Overview of Micropollutants and Sustainable Treatment Options", Journal of Hydrology,Vol. 389 (3), pp. 416-428.

Vieno, N., Tuhkanen, T., Kronberg, L., 2006, “Removal of Pharmaceuticals in Drinking Water Treatment: Effect of Chemical Coagulation", Environmental Technology,Vol. 27 (2), pp. 183192.

Westerhoff, P., Yoon, Y., Snyder, S., Wert, E., 2005, "Fate of Endocrine-disruptor, Pharmaceutical, and Personal Care Product Chemicals During Simulated Drinking Water Treatment Processes", Environmental Science \& Technology, Vol. 39 (17), pp. 6649-6663. 
Yangali-Quintanilla, V., Maeng, S.K., Fujioka, T., Kennedy, M., Li, Z., Amy, G., 2011, “Nanofiltration vs. Reverse Osmosis for The Removal of Emerging Organic Contaminants in Water Reuse", Desalination and Water Treatment, Vol. 34, pp. 50-56. 